\title{
Access to Cancer Drugs in Canada: Looking Beyond Coverage Decisions
}

\section{Accès aux médicaments pour traiter le cancer au Canada : voir au-delà des décisions concernant la couverture}

\author{
ROGER CHAFE, PHD \\ Division of Pediatrics, Faculty of Medicine \\ Memorial University \\ St. John's, NL \\ ANTHONY CULYER, HON D ECON, CBE \\ Department of Health Policy, Management and Evaluation \\ University of Toronto \\ Toronto, ON \\ MARK DOBROW, PHD \\ Cancer Services and Policy Research Unit, Cancer Care Ontario \\ Department of Health Policy, Management and Evaluation \\ University of Toronto \\ Toronto, $\mathrm{ON}$ \\ PETER C. COYTE, PHD \\ Department of Health Policy, Management and Evaluation \\ University of Toronto \\ Toronto, ON \\ CAROL SAWKA, MD \\ Clinical Programs \& Quality Initiatives, Cancer Care Ontario \\ Departments of Medicine, Public Health Sciences E Health Policy Management and Evaluation \\ University of Toronto \\ Toronto, ON \\ SUSAN O'REILLY, MD \\ Cancer Care, BC Cancer Agency \\ Vancouver, BC
}




\title{
Roger Chafe et al.
}

KARA LAING, MD

Clinical Chief, Cancer Care Program, Eastern Health

Associate Professor, Memorial University of Newfoundland

St. John's, NL

MAUREEN TRUDEAU, MD, MA

Systemic Therapy, Cancer Care Ontario

Systemic Therapy, Toronto Sunnybrook Regional Cancer Centre

Toronto, ON

SHARON SMITH, RN, MN

Program Director, Cancer Care Program, Eastern Health

St. John's NL

JEFFREY S. HOCH, PHD

Canadian Centre for Applied Research in Cancer Control (ARCC)

Li Ka Shing Knowledge Institute, St. Michael's Hospital

Department of Health Policy, Management and Evaluation

University of Toronto

Toronto, ON

STEVE MORGAN, PHD

Centre for Health Services and Policy Research

University of British Columbia

Vancouver, BC

STUART PEACOCK, PHD

Canadian Centre for Applied Research in Cancer Control

School of Population and Public Health, University of British Columbia

Vancouver, BC

RICK ABBOTT, BSCPHARM

Manager, Oncology Pharmacy Services

Cancer Care Program, Eastern Health

St. John's, NL

TERRENCE SULLIVAN, PHD

Dala Lana School of Public Health E Health Policy, Management and Evaluation

University of Toronto

Toronto, ON

\begin{abstract}
Objective: To examine variation in patients' access to a set of cancer drugs through publicly funded provincial drug programs.

Data Sources/Study Design: We surveyed provincial drug program managers about their highest-expenditure intravenous and oral cancer drugs. We then investigated whether the same cancer drugs account for the highest expenditures across the provincial programs. We also compared the rates at which these drugs are accessed through these programs.
\end{abstract}


Principal Findings: While there is moderate consistency in the selection of cancer drugs that account for the highest provincial expenditures, considerable differences were found in the rates at which some drugs are accessed across provincial programs.

Conclusions: The study demonstrates the existence of interprovincial variation in publicly funded access to cancer drugs even after these drugs have been approved for public coverage.

\section{Résumé}

Objectif : Examiner la variation dans l'accès des patients à un ensemble de médicaments pour traiter le cancer, par le biais de programmes d'assurance médicaments provinciaux financés par les fonds publics.

Sources de données/concept de l'étude : Nous avons effectué un sondage auprès de gestionnaires de programmes d'assurance médicaments provinciaux pour connaître leurs coûts de dépense les plus élevés quant aux médicaments pour traiter le cancer administrés par voie intraveineuse et orale. Nous avons ensuite comparé les résultats pour savoir si les mêmes médicaments entraînent les coûts les plus élevés parmi tous les programmes d'assurance médicaments provinciaux. Nous avons aussi comparé les taux auxquels ces médicaments sont obtenus à travers ces programmes.

Principaux résultats : Bien qu'il existe une certaine cohérence dans la liste des médicaments qui entraînent les plus grandes dépenses pour les provinces, des différences considérables ont été observées dans les taux auxquels certains médicaments sont obtenus entre les différents programmes provinciaux.

Conclusions : L'étude démontre l'existence d'une variation interprovinciale dans l'accès aux médicaments financés par les fonds publics, et ce, même après que ces médicaments aient été approuvés dans le cadre d'une couverture publique.

\section{G} iven the high cost of many cancer drugs, patients in Canada often are forced to rely on publicly funded drug programs in order to obtain care. These programs are independently run by the provinces, with each provincial government determining the structure and eligibility requirements for its own programs. These programs also independently decide which drugs will be eligible for public coverage in each province. This situation can result in cancer patients in different provinces having differential access to care.

Previous studies examining variation in access to cancer drugs have focused primarily on whether particular drugs are covered by provincial drug programs. These studies have found considerable variation in public coverage both for specific drugs (Khoo et al. 2007; Menon et al. 2005; Verma et al. 2007) and within the categories of drugs covered for various populations (Canadian Cancer Society 2009). Yet, even when provincial programs similarly agree to cover a drug, there can still be significant variation in patients' access. Although these post-coverage variations in access are less noticeable than those arising because drugs have been categorically included in or excluded from coverage, they raise similar concerns regarding equitable access 
and quality of care. To explore further the extent to which cancer patients in different provinces have differential access to care, we examined variations in the rate at which patients access a set of cancer drugs through the various provincially funded drug programs.

\section{Method}

Because some provinces provide coverage for intravenous and non-intravenous (including oral) cancer drugs through separate drug programs, we surveyed provincial drug plans for both intravenous and oral agents. We initially considered surveying the drug plans about a fixed list of cancer drugs to compare variation, similar to the approach taken by Khoo and colleagues (2007). We ultimately chose, however, to focus the survey on the top 10 oral and intravenous drugs by expenditure specific to each province. This variation was of most interest to the cancer system policy makers with whom we discussed the project. Furthermore, the top 10 drugs account for a very high proportion of total cancer drug expenditures (e.g., the top 10 intravenous cancer drugs often account for more than $90 \%$ of total program expenditures on these drugs). We were also advised that many provincial drug programs lacked the ability to provide more extensive data, so requesting information about a longer list of drugs would likely have substantially reduced the survey's response rate.

Each program manager was asked to identify the 10 intravenous and 10 oral cancer drugs accounting for the greatest expenditure in his or her province during the 2006-2007 fiscal year. Managers were asked also to itemize the annual provincial expenditure on each drug and the number of patients within their province receiving public reimbursement for the drug during that period. Reminder e-mails and follow-up telephone calls were made to survey nonrespondents over a period of three months.

\section{Results}

Eight provincial drug program managers provided data on the top 10 intravenous cancer drugs by total expenditure (Table 1, see http://www.longwoods.com/content/22177). Five intravenous cancer drugs - trastuzumab (Herceptin), rituximab (Rituxan), docetaxel (Taxotere), irinotecan (Camptosar) and gemcitabine (Gemzar) - were listed by all eight provincial programs that reported data. Paclitaxel (Taxol) and bortezomib (Velcade) were listed in the top 10 of seven programs. Oxaliplatin (Eloxatin) and epirubicin (Pharmorubicin) were listed by six of the programs.

We compared the number of top 10 intravenous drugs that each program had in common with programs in other provinces. Based on a similar interpretation of kappa statistics to that of McGinn and colleagues (2004), we categorized provinces as having "fair" agreement if they had five of the 10 drugs in common, "moderate" agreement when there were six or seven drugs in common, "substantial" agreement if they had eight or nine drugs in common and "perfect" agreement if they had the same 10 drugs listed. The number of drugs that provinces had in common ranged from five to nine, with many provinces showing substantial agreement, but no two provinces having perfect agreement. For intravenous drugs, the average was 7.8 drugs in common, indicating "moderate" to "substantial" agreement among the provinces in terms of the 
drugs on which they spent the most during the study period.

Six drug program managers provided data on oral cancer drugs (Table 2). Four oral cancer drugs - imatinib (Gleevec), anastrozole (Armidex), capecitabine (Xeloda) and letrozole (Femara) - were in the top 10 for all six provincial programs for which data were provided. Temozolomide (Temodal) was listed in the top 10 for five of the six programs. The average number of drugs in common was 5.9, indicating "fair" to "moderate" agreement among the programs.

TABLE 2. Top 10 oral cancer drugs by total provincial expenditure for 2006-2007 (per capita spending on each drug in brackets)

\begin{tabular}{|c|c|c|c|c|c|c|}
\hline & BC & $A B$ & SK & ON & NS & NL \\
\hline \multirow[t]{2}{*}{1} & $\begin{array}{l}\text { Imatinib } \\
\text { (Gleevec) }\end{array}$ & $\begin{array}{l}\text { Leuprolide } \\
\text { Gel }\end{array}$ & LHRH Analogs & $\begin{array}{l}\text { Imatinib } \\
\text { (Gleevec) }\end{array}$ & $\begin{array}{l}\text { Goserelin } \\
\text { (Zoladex) }\end{array}$ & $\begin{array}{l}\text { Imatinib } \\
\text { (Gleevec) }\end{array}$ \\
\hline & $\begin{array}{l}\$ 9,758,620 \\
(\$ 2.37)\end{array}$ & $\begin{array}{l}\$ 9,624,705 \\
(\$ 2.93)\end{array}$ & $\begin{array}{l}\$ 3,226,730 \\
(\$ 3.33)\end{array}$ & $\begin{array}{l}\$ 19,124,044 \\
(\$ 1.57)\end{array}$ & $\begin{array}{l}\$ 1,554,624 \\
(\$ 1.70)\end{array}$ & $\begin{array}{l}\$ 587,594 \\
(\$ 1.16)\end{array}$ \\
\hline \multirow[t]{2}{*}{2} & $\begin{array}{l}\text { Goserelin } \\
\text { (Zoladex) }\end{array}$ & $\begin{array}{l}\text { Imatinib } \\
\text { (Gleevec) }\end{array}$ & $\begin{array}{l}\text { Imatinib } \\
\text { (Gleevec) }\end{array}$ & $\begin{array}{l}\text { Anastrozole } \\
\text { (Arimidex) }\end{array}$ & Leuprolide & Bicalutamide \\
\hline & $\begin{array}{l}\$ 7,047,846 \\
(\$ 1.71)\end{array}$ & $\begin{array}{l}\$ 6,623,894 \\
(\$ 2.01)\end{array}$ & $\begin{array}{l}\$ 2,113,799 \\
(\$ 2.18)\end{array}$ & $\begin{array}{l}\$ 10,268,736 \\
(\$ 0.84)\end{array}$ & $\begin{array}{l}\$ 1,035,401 \\
(\$ 1.13)\end{array}$ & $\begin{array}{l}\$ 214,669 \\
(\$ 0.42)\end{array}$ \\
\hline \multirow[t]{2}{*}{3} & Leuprolide & $\begin{array}{l}\text { Temozolomide } \\
\text { (Temodal) }\end{array}$ & $\begin{array}{l}\text { Filgrastim } \\
\text { (G-CSF- } \\
\text { Neupogen) }\end{array}$ & Bicalutamide & $\begin{array}{l}\text { Imatinib } \\
\text { (Gleevec) }\end{array}$ & $\begin{array}{l}\text { Erlotinib } \\
\text { (Tarceva) }\end{array}$ \\
\hline & $\begin{array}{l}\$ 5,599,655 \\
(\$ 1.36)\end{array}$ & $\begin{array}{l}\$ 2,035,920 \\
(\$ 0.62)\end{array}$ & $\begin{array}{l}\$ 1,350,677 \\
(\$ 1.40)\end{array}$ & $\begin{array}{l}\$ 8,923,072 \\
(\$ 0.73)\end{array}$ & $\begin{array}{l}\$ 804,872 \\
(\$ 0.88)\end{array}$ & $\begin{array}{l}\$ 91,642 \\
(\$ 0.18)\end{array}$ \\
\hline \multirow[t]{2}{*}{4} & $\begin{array}{l}\text { Anastrazole } \\
\text { (Armidex) }\end{array}$ & $\begin{array}{l}\text { Capecitabine } \\
\text { (Xeloda) }\end{array}$ & $\begin{array}{l}\text { Temozolomide } \\
\text { (Temodal) }\end{array}$ & $\begin{array}{l}\text { Letrozole } \\
\text { (Femara) }\end{array}$ & $\begin{array}{l}\text { Anastrozole } \\
\text { (Arimidex) }\end{array}$ & $\begin{array}{l}\text { Anastrozole } \\
\text { (Arimidex) }\end{array}$ \\
\hline & $\begin{array}{l}\$ 3,243,415 \\
(\$ 0.79)\end{array}$ & $\begin{array}{l}\$ 1,708,605 \\
(\$ 0.52)\end{array}$ & $\begin{array}{l}\$ 562,519 \\
(\$ 0.58)\end{array}$ & $\begin{array}{l}\$ 5,721,234 \\
(\$ 0.47)\end{array}$ & $\begin{array}{l}\$ 706,940 \\
(\$ 0.77)\end{array}$ & $\begin{array}{l}\$ 88,370 \\
(\$ 0.17)\end{array}$ \\
\hline \multirow[t]{2}{*}{5} & $\begin{array}{l}\text { Octreotide } \\
\text { (Sandostatin) }\end{array}$ & $\begin{array}{l}\text { Anastrozole } \\
\text { (Arimidex) }\end{array}$ & $\begin{array}{l}\text { Octreotide } \\
\text { (Sandostatin) }\end{array}$ & $\begin{array}{l}\text { Temozolomide } \\
\text { (Temodal) }\end{array}$ & Biclutamide & $\begin{array}{l}\text { Capecitabine } \\
\text { (Xeloda) }\end{array}$ \\
\hline & $\begin{array}{l}\$ 3,182,578 \\
(\$ 0.77)\end{array}$ & $\begin{array}{l}\$ 1,587,286 \\
(\$ 0.48)\end{array}$ & $\begin{array}{l}\$ 536,519 \\
(\$ 0.55)\end{array}$ & $\begin{array}{l}\$ 5,685,|4| \\
(\$ 0.47)\end{array}$ & $\begin{array}{l}\$ 610,836 \\
(\$ 0.67)\end{array}$ & $\begin{array}{l}\$ 73,568 \\
(\$ 0.15)\end{array}$ \\
\hline \multirow[t]{2}{*}{6} & $\begin{array}{l}\text { Letrozole } \\
\text { (Femara) }\end{array}$ & $\begin{array}{l}\text { Letrozole } \\
\text { (Femara) }\end{array}$ & $\begin{array}{l}\text { Anastrozole } \\
\text { (Arimidex) }\end{array}$ & $\begin{array}{l}\text { Capecitabine } \\
\text { (Xeloda) }\end{array}$ & $\begin{array}{l}\text { Letrozole } \\
\text { (Femara) }\end{array}$ & $\begin{array}{l}\text { Letrozole } \\
\text { (Femara) }\end{array}$ \\
\hline & $\begin{array}{l}\$ 2,594,166 \\
(\$ 0.63)\end{array}$ & $\begin{array}{l}\$ 1,066,913 \\
(\$ 0.32)\end{array}$ & $\begin{array}{l}\$ 516,696 \\
(\$ 0.53)\end{array}$ & $\begin{array}{l}\$ 4,294,417 \\
(\$ 0.35)\end{array}$ & $\begin{array}{l}\$ 330,487 \\
(\$ 0.36)\end{array}$ & $\begin{array}{l}\$ 64,807 \\
(\$ 0.13)\end{array}$ \\
\hline \multirow[t]{2}{*}{7} & $\begin{array}{l}\text { Temozolomide } \\
\text { (Temodal) }\end{array}$ & Thalidomide & $\begin{array}{l}\text { Capecitabine } \\
\text { (Xeloda) }\end{array}$ & Methotrexate & $\begin{array}{l}\text { Temozolomide } \\
\text { (Temodal) }\end{array}$ & Tamoxifen \\
\hline & $\begin{array}{l}\$ 2,554,144 \\
(\$ 0.62)\end{array}$ & $\begin{array}{l}\$ 991,811 \\
(\$ 0.30)\end{array}$ & $\begin{array}{l}\$ 427,256 \\
(\$ 0.44)\end{array}$ & $\begin{array}{l}\$ 2,332,915 \\
(\$ 0.19)\end{array}$ & $\begin{array}{l}\$ 290,825 \\
(\$ 0.32)\end{array}$ & $\begin{array}{l}\$ 33,530 \\
(\$ 0.07)\end{array}$ \\
\hline
\end{tabular}


TABLE 2. Continued.

\begin{tabular}{|c|c|c|c|c|c|c|}
\hline & BC & $\mathbf{A B}$ & SK & ON & NS & NL \\
\hline 8 & $\begin{array}{l}\text { Capecitabine } \\
(\text { Xeloda }) \\
\$ 2,554,144 \\
(\$ 0.62)\end{array}$ & $\begin{array}{l}\text { Interferon } \\
\$ 837,077 \\
(\$ 0.25)\end{array}$ & $\begin{array}{l}\text { Interferon } \\
\$ 212,617 \\
(\$ 0.22)\end{array}$ & $\begin{array}{l}\text { Erlotinib } \\
\text { (Tarceva) } \\
\$ 2,311,408 \\
(\$ 0.19)\end{array}$ & $\begin{array}{l}\text { Capecitabine } \\
\text { (Xeloda) } \\
\$ 250,552 \\
(\$ 0.27)\end{array}$ & $\begin{array}{l}\text { Hydroxy- } \\
\text { carbamide } \\
\$ 30,794 \\
(\$ 0.06)\end{array}$ \\
\hline 9 & $\begin{array}{l}\text { Exemestane } \\
\text { (Aromasin) } \\
\$ 1,287,568 \\
(\$ 0.31)\end{array}$ & $\begin{array}{l}\text { Erlotinib } \\
\text { (Tarceva) } \\
\$ 750,113 \\
(\$ 0.23)\end{array}$ & $\begin{array}{l}\text { Letrozole } \\
\text { (Femara) } \\
\$ 199,950 \\
(\$ 0.21)\end{array}$ & $\begin{array}{l}\text { Exemestane } \\
\text { (Aromasin) } \\
\$ 1,566,691 \\
(\$ 0.13)\end{array}$ & $\begin{array}{l}\text { Buserelin } \\
\$ 182,180 \\
(\$ 0.20)\end{array}$ & $\begin{array}{l}\text { Megestrol } \\
\text { (Megace) } \\
\$ 19,461 \\
(\$ 0.04)\end{array}$ \\
\hline 10 & $\begin{array}{l}\text { Buserelin } \\
\$ 1,270,427 \\
(\$ 0.31)\end{array}$ & $\begin{array}{l}\text { Fludarabine } \\
\$ 571,044 \\
(\$ 0.17)\end{array}$ & $\begin{array}{l}\text { Ondansetron/ } \\
\text { Granisetron } \\
\$ 180,651 \\
(\$ 0.19)\end{array}$ & $\begin{array}{l}\text { Megestrol } \\
\text { (Megace) } \\
\$ 1,490,249 \\
(\$ 0.12)\end{array}$ & $\begin{array}{l}\text { Methotrexate } \\
\$ 180,816 \\
(\$ 0.20)\end{array}$ & $\begin{array}{l}\text { Exemestane } \\
\text { (Aromasin) } \\
\$ 18,009 \\
(\$ 0.04)\end{array}$ \\
\hline
\end{tabular}

For the five intravenous and four oral drugs for which all the reporting provinces provided data, we examined variation in their utilization. This analysis was constrained by the fact that only six provinces provided any data on the number of patients obtaining the drugs during the study period.

Table 3 shows the utilization rate per 100,000 population for each drug for provinces that reported patient utilization data.

TABLE 3. Number of patients per 100,000 population receiving a cancer drug through a public drug program for selected high-expenditure cancer drugs

\begin{tabular}{|c|c|c|c|c|c|c|c|c|c|}
\hline \multirow[t]{2}{*}{ Drug } & \multirow[t]{2}{*}{ Type } & \multicolumn{6}{|c|}{ Provinces } & \multirow{2}{*}{$\begin{array}{c}\text { Mean } \\
\text { Number } \\
\text { per } 100,000 \\
\text { Receiving } \\
\text { Drug }\end{array}$} & \multirow{2}{*}{$\begin{array}{c}\text { Coefficient } \\
\text { of } \\
\text { Variation }\end{array}$} \\
\hline & & BC & $\mathbf{A B}$ & MB & SK & ON & NL & & \\
\hline Anastrozole & Oral & 60.3 & 28.6 & $x$ & 39.2 & 58.2 & 13.9 & 40.0 & $49.3 \%$ \\
\hline Letrozole & Oral & 50.5 & 24.1 & $x$ & 19.8 & 32.5 & 10.3 & 27.4 & $55.3 \%$ \\
\hline Docetaxel & IV & 21.3 & 19.5 & 22.5 & 19.7 & 23.7 & $x$ & 21.3 & $8.4 \%$ \\
\hline Rituximab & IV & 25.7 & 14.3 & 24.4 & 20.0 & 18.7 & $x$ & 20.6 & $22.1 \%$ \\
\hline Gemcitabine & IV & 24.0 & 10.3 & 18.7 & 23.5 & 15.4 & $x$ & 18.4 & $31.2 \%$ \\
\hline Capecitabine & Oral & 28.1 & 18.4 & $x$ & 18.3 & 14.3 & 4.8 & 16.8 & $50.2 \%$ \\
\hline Trastuzumab & IV & 20.0 & 12.8 & 17.2 & 15.9 & 17.4 & $x$ & 16.7 & $15.8 \%$ \\
\hline Irinotecan & IV & 13.6 & 9.2 & 20.7 & 16.2 & 15.3 & $x$ & 15.0 & $27.8 \%$ \\
\hline Imatinib & Oral & 8.3 & 6.6 & $x$ & 9.0 & 5.0 & 3.2 & 6.4 & $37.2 \%$ \\
\hline
\end{tabular}




\section{Interpretation}

Access to cancer drugs in Canada is complicated. Previous studies have examined differences in coverage between provinces or have pointed out gaps in eligibility for coverage for some types of cancer drugs. Our study expanded on this work by examining variations in access to the cancer drugs funded through provincial drug programs. This study thus captures the combined effect of coverage decisions for specific drugs, eligibility requirements of public coverage and other factors that may affect access through publicly funded drug programs in each province.

We found moderate to substantial agreement in the cancer drugs accounting for the highest expenditures across provincial programs. This level of agreement existed notwithstanding the variation in eligibility for public coverage during the survey period. For example, bevacizumab (Avastin) was one of the top 10 highest-expenditure drugs in only two provinces: British Columbia and Newfoundland and Labrador. These provinces, however, were the only two that covered bevacizumab during the study period. This level of agreement among highexpenditure drugs suggests that there may be less variation in access to many key cancer drugs than has been suggested by other studies (Menon et al. 2005). In other words, despite the concern about variations in access across the provinces, the provincial drug programs do generally spend the majority of their budgets on the same small portfolio of drugs.

Our data also show the impact that different program structures have on the rate of publicly funded drug utilization among the provinces. For example, there is almost a threefold difference between Saskatchewan (which offers universal coverage) and Newfoundland (which offers coverage for oral cancer drugs only to those who qualify for its general pharmaceutical assistance program) in the rate at which patients receive imatinib (Gleevec). Given that the average annual cost per patient of imatinib reported in our survey was $\$ 30,268$, these differences in the rates of access across the publicly funded drug programs clearly raise difficult equity issues and can have significant financial implications for individual patients. We also found, however, large variation in utilization for some drugs between programs with similar eligibility structures. British Columbian data indicate that 60 patients per 100,000 population receive anastrozole (Arimidex) through their public drug program compared with 29 patients per 100,000 population in Alberta, even though both provinces offer universal coverage. Further clinical, epidemiological and administrative analyses are needed to determine the reasons for variations concerning specific drugs when provincial drug coverage is similar and to determine whether opportunities exist for improving the effectiveness and efficiency of care (Blumenthal 1994).

A key barrier to understanding the reasons for variation is the lack of information systems for capturing the required data. It was notable that several provinces reported difficulties retrieving even basic information about drug utilization, including the number of patients who are obtaining them through public drug programs and the condition for which a patient is receiving a drug. Although most drug program managers indicated a willingness to be involved in the survey, it took over 10 months for some of them to compile and submit the data. Given the amount of public resources being spent on cancer drugs (see Tables 1 and 3) and their importance in patient care, there needs to be better data capture by many of the provincial drug programs to ensure that these drugs are being used effectively and efficiently. 


\section{Conclusion}

Interprovincial variation in access to cancer drugs is often presented as a criticism of provincial drug programs (Brach 2008; Priest 2007). The Pan-Canadian Oncology Drug Review, which aims to better coordinate the review of cancer drugs across nine of the 10 provinces, is a step in the right direction (Government of Ontario 2010) and may lead to more convergence in coverage recommendations, as seems to have occurred for other pharmaceuticals following the establishment of the Common Drug Review (Tierney and Manns 2008). Our study, however, illustrates that there are other important variations in Canadians' publicly funded access to cancer drugs, even after these drugs have been approved for public coverage, which need to be examined further. An important focus of future research should be on the effect that these interprovincial variations have on patients' ultimate access to these drugs (Berry et al. 2007) and on patient outcomes. After all, the Canadian healthcare system is based on the ideal that access to care should be based on need rather than place of residence or ability to pay. Policy makers need to recognize that there is more involved in ensuring equitable access to these drugs than simply taking the first step of making them eligible for public coverage.

\section{ACKNOWLEDGEMENTS}

This research project was funded by a CIHR Partnerships in Health System Improvement Grant.

Correspondence may be directed to: Dr. Roger Chafe, Director of Pediatric Research, The Janeway Pediatric Research Unit, Room 409, Janeway Hostel, Memorial University of Newfoundland, 300 Prince Philip Drive, St. John's, NL A1B 3V6; tel.: 709-777-2944; e-mail: roger.chafe@med. mun.ca.

\section{REFERENCES}

Berry, S.R., S. Hubay, H. Soibelman and D. Martin. 2007.“The Effect of Priority Setting Decisions for New Cancer Drugs on Medical Oncologists' Practice in Ontario: A Qualitative Study." BMC Health Services Research 7: 193. doi:10.1186/1472-6963-7-193.

Blumenthal, D. 1994. “The Variation Phenomenon in 1994.” New England Journal of Medicine 49: 27-36.

Brach, B. 2008 (February 13). “Cancer Treatment 'Inconsistent, Unfair': Study.” National Post. Retrieved January 12, 2011. <http://www.nationalpost.com/news/canada/story.html?id=304099>.

Canadian Cancer Society. Cancer Drug Access for Canadians, 2009. Retrieved January 12, 2011. <http://www. cancer.ca/Canada-wide/About\%20us/Media\%20centre/CW-Media\%20releases/CW-2009/ /media/CCS/ Canada\%20wide/Files\%20List/English\%20files\%20heading/pdf\%20not\%20in\%20publications\%20section/ CANCER\%20DRUG\%20ACCESS\%20FINAL\%20-\%20English.ashx>.

Government of Ontario. 2010. Inter-Provincial Joint Oncology Drug Review Process. Retrieved January 12, 2011. $<$ http://www.health.gov.on.ca/english/providers/program/drugs/drug_submissions/inter_oncology_drugs.html>.

Khoo, K., R. Colucci, W. Hryniuk, J. Ragaz, S. Sehdev and C. Savage. 2007. Cancer Drug Access, Part Three: The New Wave of Cancer Drugs. Report Card on Cancer in Canada. Toronto: Cancer Advocacy Coalition of Canada. Retrieved January 12, 2011. <http://www.canceradvocacy.ca/reportcard/2007/Report\%20Card\%20on\%20 Cancer\%20in\%20Canada,\%202007.pdf > . 
McGinn, T., P.C. Wyer, T.B. Newman, S. Keitz, R. Leipzig and G. Guyatt. 2004. “Tips for Learners of EvidenceBased Medicine: 3. Measures of Observer Variability (Kappa Statistic)." Canadian Medical Association Journal 171: 1369-73. doi:10.1503/cmaj.1031981.

Menon, D.S., T. Stafinski and G. Stuart. 2005. "Access to Drugs for Cancer: Does Where You Live Matter?" Canadian Journal of Public Health 96(6): 454-58.

Priest, L. 2007 (October 5). “Getting a Grip on Effective Cancer Treatments.” The Globe and Mail. Retrieved January 12, 2011. <http://v1.theglobeandmail.com/servlet/story/RTGAM.20071005.ont-health05/BNStory/ ontarioelection2007/LISA+PRIEST/>.

Tierney, M. and B. Manns. 2008. "Optimizing the Use of Prescription Drugs in Canada through the Common Drug Review." Canadian Medical Association Journal 178: 432-35. doi:10.1503/cmaj.070713.

Verma, S., S. Sehdev and A.A. Joy. 2007. “Cancer Therapy Disparity: Unequal Access to Breast Cancer Therapeutics and Drug Funding in Canada." Current Oncology 14 (Suppl. 1): S3-S10.

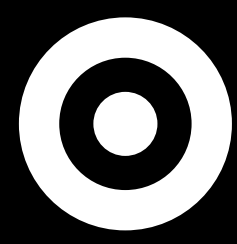

Target your job search here.

\section{jobs.Longwoods.com}


TABLE 1. Top 10 intravenous cancer drugs by total provincial expenditure for 2006-2007 (per capita spending on each drug in brackets)

\begin{tabular}{|c|c|c|c|c|c|c|c|c|}
\hline & BC & $\mathbf{A B}$ & SK & MB & ON & NB & NS & NL \\
\hline \multirow[t]{2}{*}{ I } & $\begin{array}{l}\text { Trastuzumab } \\
\text { (Herceptin) }\end{array}$ & $\begin{array}{l}\text { Trastuzumab } \\
\text { (Herceptin) }\end{array}$ & $\begin{array}{l}\text { Trastuzumab } \\
\text { (Herceptin) }\end{array}$ & $\begin{array}{l}\text { Trastuzumab } \\
\text { (Herceptin) }\end{array}$ & $\begin{array}{l}\text { Trastuzumab } \\
\text { (Herceptin) }\end{array}$ & $\begin{array}{l}\text { Rituximab } \\
\text { (Rituxan) }\end{array}$ & $\begin{array}{l}\text { Trastuzumab } \\
\text { (Herceptin) }\end{array}$ & $\begin{array}{l}\text { Oxaliplatin } \\
\text { (Eloxatin) }\end{array}$ \\
\hline & $\begin{array}{l}\$ 18,898,738 \\
(\$ 4.59)\end{array}$ & $\begin{array}{l}\$ 11,782,800 \\
(\$ 3.58)\end{array}$ & $\begin{array}{l}\$ 4,087,800 \\
(\$ 4.22)\end{array}$ & $\begin{array}{l}\$ 4,680,202 \\
(\$ 4.08)\end{array}$ & $\begin{array}{l}\$ 51,328,968 \\
(\$ 4.22)\end{array}$ & $\begin{array}{l}\$ 3,226,644 \\
(\$ 4.42)\end{array}$ & $\begin{array}{l}\$ 3,240,000 \\
(\$ 3.55)\end{array}$ & $\begin{array}{l}\$ 2,306,228 \\
(\$ 4.56)\end{array}$ \\
\hline \multirow[t]{2}{*}{2} & $\begin{array}{l}\text { Rituximab } \\
\text { (Rituxan) }\end{array}$ & $\begin{array}{l}\text { Rituximab } \\
\text { (Rituxan) }\end{array}$ & $\begin{array}{l}\text { Rituximab } \\
\text { (Rituxan) }\end{array}$ & $\begin{array}{l}\text { Rituximab } \\
\text { (Rituxan) }\end{array}$ & $\begin{array}{l}\text { Rituximab } \\
\text { (Rituxan) }\end{array}$ & $\begin{array}{l}\text { Trastuzumab } \\
\text { (Herceptin) }\end{array}$ & $\begin{array}{l}\text { Rituximab } \\
\text { (Rituxan) }\end{array}$ & $\begin{array}{l}\text { Trastuzumab } \\
\text { (Herceptin) }\end{array}$ \\
\hline & $\begin{array}{l}\$|4,790,87| \\
(\$ 3.60)\end{array}$ & $\begin{array}{l}\$ 7,926,078 \\
(\$ 2.41)\end{array}$ & $\begin{array}{l}\$ 2,686,833 \\
(\$ 2.78)\end{array}$ & $\begin{array}{l}\$ 3,466,541 \\
(\$ 3.02)\end{array}$ & $\begin{array}{l}\$ 30,788,293 \\
(\$ 2.53)\end{array}$ & $\begin{array}{l}\$ 2,347,910 \\
(\$ 3.22)\end{array}$ & $\begin{array}{l}\$ 3,117,328 \\
(\$ 3.41)\end{array}$ & $\begin{array}{l}\$ 2,019,600 \\
(\$ 4.00)\end{array}$ \\
\hline \multirow[t]{2}{*}{3} & $\begin{array}{l}\text { Oxaliplatin } \\
\text { (Eloxatin) }\end{array}$ & $\begin{array}{l}\text { Docetaxel } \\
\text { (Taxotere) }\end{array}$ & $\begin{array}{l}\text { Irinotecan } \\
\text { (Camptosar) }\end{array}$ & $\begin{array}{l}\text { Irinotecan } \\
\text { (Camptosar) }\end{array}$ & $\begin{array}{l}\text { Docetaxel } \\
\text { (Taxotere) }\end{array}$ & $\begin{array}{l}\text { Oxaliplatin } \\
\text { (Eloxatin) }\end{array}$ & $\begin{array}{l}\text { Docetaxel } \\
\text { (Taxotere) }\end{array}$ & $\begin{array}{l}\text { Bevacizumab } \\
\text { (Avastin) }\end{array}$ \\
\hline & $\begin{array}{l}\$ 8,468,959 \\
(\$ 2.06)\end{array}$ & $\begin{array}{l}\$ 5,029,310 \\
(\$ 1.53)\end{array}$ & $\begin{array}{l}\$ 1,030,772 \\
(\$ 1.06)\end{array}$ & $\begin{array}{l}\$ 1,946,533 \\
(\$ 1.69)\end{array}$ & $\begin{array}{l}\$ 16,839,367 \\
(\$ 1.38)\end{array}$ & $\begin{array}{l}\$ 1,440,550 \\
(\$ 1.97)\end{array}$ & $\begin{array}{l}\$ 1,148,518 \\
(\$ 1.26)\end{array}$ & $\begin{array}{l}\$ 1,870,000 \\
(\$ 3.70)\end{array}$ \\
\hline \multirow[t]{2}{*}{4} & $\begin{array}{l}\text { Bevacizumab } \\
\text { (Avastin) }\end{array}$ & $\begin{array}{l}\text { Oxaliplatin } \\
\text { (Eloxatin) }\end{array}$ & $\begin{array}{l}\text { Docetaxel } \\
\text { (Taxotere) }\end{array}$ & $\begin{array}{l}\text { Docetaxel } \\
\text { (Taxotere) }\end{array}$ & $\begin{array}{l}\text { Irinotecan } \\
\text { (Camptosar) }\end{array}$ & $\begin{array}{l}\text { Docetaxel } \\
\text { (Taxotere) }\end{array}$ & $\begin{array}{l}\text { Irinotecan } \\
\text { (Camptosar) }\end{array}$ & $\begin{array}{l}\text { Docetaxel } \\
\text { (Taxotere) }\end{array}$ \\
\hline & $\begin{array}{l}\$ 5,228,970 \\
(\$ 1.27)\end{array}$ & $\begin{array}{l}\$ 1,534,004 \\
(\$ 0.47)\end{array}$ & $\begin{array}{l}\$ 945,866 \\
(\$ 0.98)\end{array}$ & $\begin{array}{l}\$ 1,499,354 \\
(\$ 1.31)\end{array}$ & $\begin{array}{l}\$ 9,750,406 \\
(\$ 0.80)\end{array}$ & $\begin{array}{l}\$ 1,023,054 \\
(\$ 1.40)\end{array}$ & $\begin{array}{l}\$ 869,688 \\
(\$ 0.95)\end{array}$ & $\begin{array}{l}\$ 1,180,168 \\
(\$ 2.33)\end{array}$ \\
\hline \multirow[t]{2}{*}{5} & $\begin{array}{l}\text { Docetaxel } \\
\text { (Taxotere) }\end{array}$ & $\begin{array}{l}\text { Epirubicin } \\
\text { (Pharmo- } \\
\text { rubicin) }\end{array}$ & $\begin{array}{l}\text { Oxaliplatin } \\
\text { (Eloxatin) }\end{array}$ & $\begin{array}{l}\text { Paciltaxel } \\
\text { (Taxol) }\end{array}$ & $\begin{array}{l}\text { Gemcitabine } \\
\text { (Gemzar) }\end{array}$ & $\begin{array}{l}\text { Irinotecan } \\
\text { (Camptosar) }\end{array}$ & $\begin{array}{l}\text { Oxaliplatin } \\
\text { (Eloxatin) }\end{array}$ & $\begin{array}{l}\text { Irinotecan } \\
\text { (Camptosar) }\end{array}$ \\
\hline & $\begin{array}{l}\$ 4,893,147 \\
(\$ 1.19)\end{array}$ & $\begin{array}{l}\$ 1,509,866 \\
(\$ 0.46)\end{array}$ & $\begin{array}{l}\$ 871,186 \\
(\$ 0.90)\end{array}$ & $\begin{array}{l}\$ 1,080,120 \\
(\$ 0.94)\end{array}$ & $\begin{array}{l}\$ 5,650,068 \\
(\$ 0.46)\end{array}$ & $\begin{array}{l}\$ 5 I 5,452 \\
(\$ 0.7 I)\end{array}$ & $\begin{array}{l}\$ 787,733 \\
(\$ 0.86)\end{array}$ & $\begin{array}{l}\$ 585,680 \\
(\$ 1.16)\end{array}$ \\
\hline \multirow[t]{2}{*}{6} & $\begin{array}{l}\text { Gemcitabine } \\
\text { (Gemzar) }\end{array}$ & $\begin{array}{l}\text { Irinotecan } \\
\text { (Camptosar) }\end{array}$ & $\begin{array}{l}\text { Gemcitabine } \\
\text { (Gemzar) }\end{array}$ & $\begin{array}{l}\text { Goserelin } \\
\text { (Zoladex) }\end{array}$ & $\begin{array}{l}\text { Paclitaxel } \\
\text { (Taxol) }\end{array}$ & $\begin{array}{l}\text { Gemcitabine } \\
\text { (Gemzar) }\end{array}$ & $\begin{array}{l}\text { Gemcitabine } \\
\text { (Gemzar) }\end{array}$ & $\begin{array}{l}\text { Epirubicin } \\
\text { (Pharmo- } \\
\text { rubicin) }\end{array}$ \\
\hline & $\begin{array}{l}\$ 2,958,344 \\
(\$ 0.72)\end{array}$ & $\begin{array}{l}\$ 1,485,473 \\
(\$ 0.45)\end{array}$ & $\begin{array}{l}\$ 692,074 \\
(\$ 0.7 I)\end{array}$ & $\begin{array}{l}\$ 604,706 \\
(\$ 0.53)\end{array}$ & $\begin{array}{l}\$ 4,419,378 \\
(\$ 0.36)\end{array}$ & $\begin{array}{l}\$ 457,409 \\
(\$ 0.63)\end{array}$ & $\begin{array}{l}\$ 755,321 \\
(\$ 0.83)\end{array}$ & $\begin{array}{l}\$ 528,612 \\
(\$ 1.05)\end{array}$ \\
\hline \multirow[t]{2}{*}{7} & $\begin{array}{l}\text { Irinotecan } \\
\text { (Camptosar) }\end{array}$ & $\begin{array}{l}\text { Gemcitabine } \\
\text { (Gemzar) }\end{array}$ & $\begin{array}{l}\text { Paclitaxel } \\
\text { (Taxol) }\end{array}$ & $\begin{array}{l}\text { Gemcitabine } \\
\text { (Gemzar) }\end{array}$ & $\begin{array}{l}\text { Epirubicin } \\
\text { (Pharmo- } \\
\text { rubicin) }\end{array}$ & $\begin{array}{l}\text { Bortezomib } \\
\text { (Velcade) }\end{array}$ & $\begin{array}{l}\text { Epirubicin } \\
\text { (Pharmo- } \\
\text { rubicin) }\end{array}$ & $\begin{array}{l}\text { Rituximab' } \\
\text { (Rituxan) }\end{array}$ \\
\hline & $\begin{array}{l}\$ 2,235,550 \\
(\$ 0.54)\end{array}$ & $\begin{array}{l}\$ 1,434,366 \\
(\$ 0.44)\end{array}$ & $\begin{array}{l}\$ 581,457 \\
(\$ 0.60)\end{array}$ & $\begin{array}{l}\$ 579,406 \\
(\$ 0.50)\end{array}$ & $\begin{array}{l}\$ 3,8 \mid 4,767 \\
(\$ 0.3 \mid)\end{array}$ & $\begin{array}{l}\$ 435,690 \\
(\$ 0.60)\end{array}$ & $\begin{array}{l}\$ 491,143 \\
(\$ 0.54)\end{array}$ & $\begin{array}{l}\$ 3 \mid 5,356 \\
(\$ 0.62)\end{array}$ \\
\hline \multirow[t]{2}{*}{8} & $\begin{array}{l}\text { Paclitaxel } \\
\text { (Taxol) }\end{array}$ & $\begin{array}{l}\text { Bortezomib } \\
\text { (Velcade) }\end{array}$ & $\begin{array}{l}\text { Doxorubicin } \\
\text { Liposome } \\
\text { (Caelyx) }\end{array}$ & $\begin{array}{l}\text { Leuprolide } \\
\text { Acetate } \\
\text { (Eligard) }\end{array}$ & $\begin{array}{l}\text { Bortezomib } \\
\text { (Velcade) }\end{array}$ & $\begin{array}{l}\text { Cetuximab } \\
\text { (Erbitux) }\end{array}$ & $\begin{array}{l}\text { Doxorubicin } \\
\text { Pegylated } \\
\text { (Adriamycin) }\end{array}$ & $\begin{array}{l}\text { Gemcitabine } \\
\text { (Gemzar) }\end{array}$ \\
\hline & $\begin{array}{l}\$ 1,519,913 \\
(\$ 0.37)\end{array}$ & $\begin{array}{l}\$ 1,144,368 \\
(\$ 0.35)\end{array}$ & $\begin{array}{l}\$ 308,7 \mid 6 \\
(\$ 0.32)\end{array}$ & $\begin{array}{l}\$ 536,874 \\
(\$ 0.47)\end{array}$ & $\begin{array}{l}\$ 3,534,746 \\
(\$ 0.29)\end{array}$ & $\begin{array}{l}\$ 417,215 \\
(\$ 0.57)\end{array}$ & $\begin{array}{l}\$ 456,244 \\
(\$ 0.50)\end{array}$ & $\begin{array}{l}\$ 260,040 \\
(\$ 0.51)\end{array}$ \\
\hline 9 & $\begin{array}{l}\text { Epirubicin } \\
\text { (Pharmo- } \\
\text { rubicin) } \\
\$ 1,504,916 \\
(\$ 0.37)\end{array}$ & $\begin{array}{l}\text { Doxorubicin } \\
\text { Liposome } \\
\text { (Doxil) } \\
\$ 752,666 \\
(\$ 0.23)\end{array}$ & $\begin{array}{l}\text { Epirubicin } \\
\text { (Pharmo- } \\
\text { rubicin) } \\
\$ 268,184 \\
(\$ 0.28)\end{array}$ & $\begin{array}{l}\text { Leuprolide } \\
\text { Acetate } \\
\text { (Eligard) } \\
\$ 5 \mid 2,22 \text { I } \\
(\$ 0.45)\end{array}$ & $\begin{array}{l}\text { Pamidronate } \\
\text { (Aredia) } \\
\$ 3,423,262 \\
(\$ 0.28)\end{array}$ & $\begin{array}{l}\text { Epirubicin } \\
\text { (Pharmo- } \\
\text { rubicin) } \\
\$ 368,835 \\
(\$ 0.51)\end{array}$ & $\begin{array}{l}\begin{array}{l}\text { Paclitaxell } \\
\text { (Taxol) }\end{array} \\
\$ 307,977 \\
(\$ 0.34)\end{array}$ & $\begin{array}{l}\text { Doxorubicin } \\
\text { Liposome } \\
\text { (Caelyx) } \\
\$ 150,000 \\
(\$ 0.30)\end{array}$ \\
\hline \multirow[t]{2}{*}{10} & $\begin{array}{l}\text { Bortezomib } \\
\text { (Velcade) }\end{array}$ & $\begin{array}{l}\text { Paclitaxell } \\
\text { (Taxol) }\end{array}$ & $\begin{array}{l}\text { Bortezomib } \\
\text { (Velcade) }\end{array}$ & $\begin{array}{l}\text { Bortezomib } \\
\text { (Velcade) }\end{array}$ & $\begin{array}{l}\text { Zolendronic } \\
\text { Acid }\end{array}$ & $\begin{array}{l}\text { Paclitaxel } \\
\text { (Taxol) }\end{array}$ & $\begin{array}{l}\text { Bortezomib } \\
\text { (Velcade) }\end{array}$ & Cisplatin \\
\hline & $\begin{array}{l}\$ 1,175,440 \\
(\$ 0.29)\end{array}$ & $\begin{array}{l}\$ 7 \mid 2,595 \\
(\$ 0.22)\end{array}$ & $\begin{array}{l}\$ 160,706 \\
(\$ 0.17)\end{array}$ & $\begin{array}{l}\$ 335,034 \\
(\$ 0.29)\end{array}$ & $\begin{array}{l}\$ 2,585,663 \\
(\$ 0.21)\end{array}$ & $\begin{array}{l}\$ 251,173 \\
(\$ 0.34)\end{array}$ & $\begin{array}{l}\$ 280,794 \\
(\$ 0.31)\end{array}$ & $\begin{array}{l}\$ 128,720 \\
(\$ 0.25)\end{array}$ \\
\hline
\end{tabular}

